Historic, Archive Document

Do not assume content reflects current scientific knowledge, policies, or practices. 



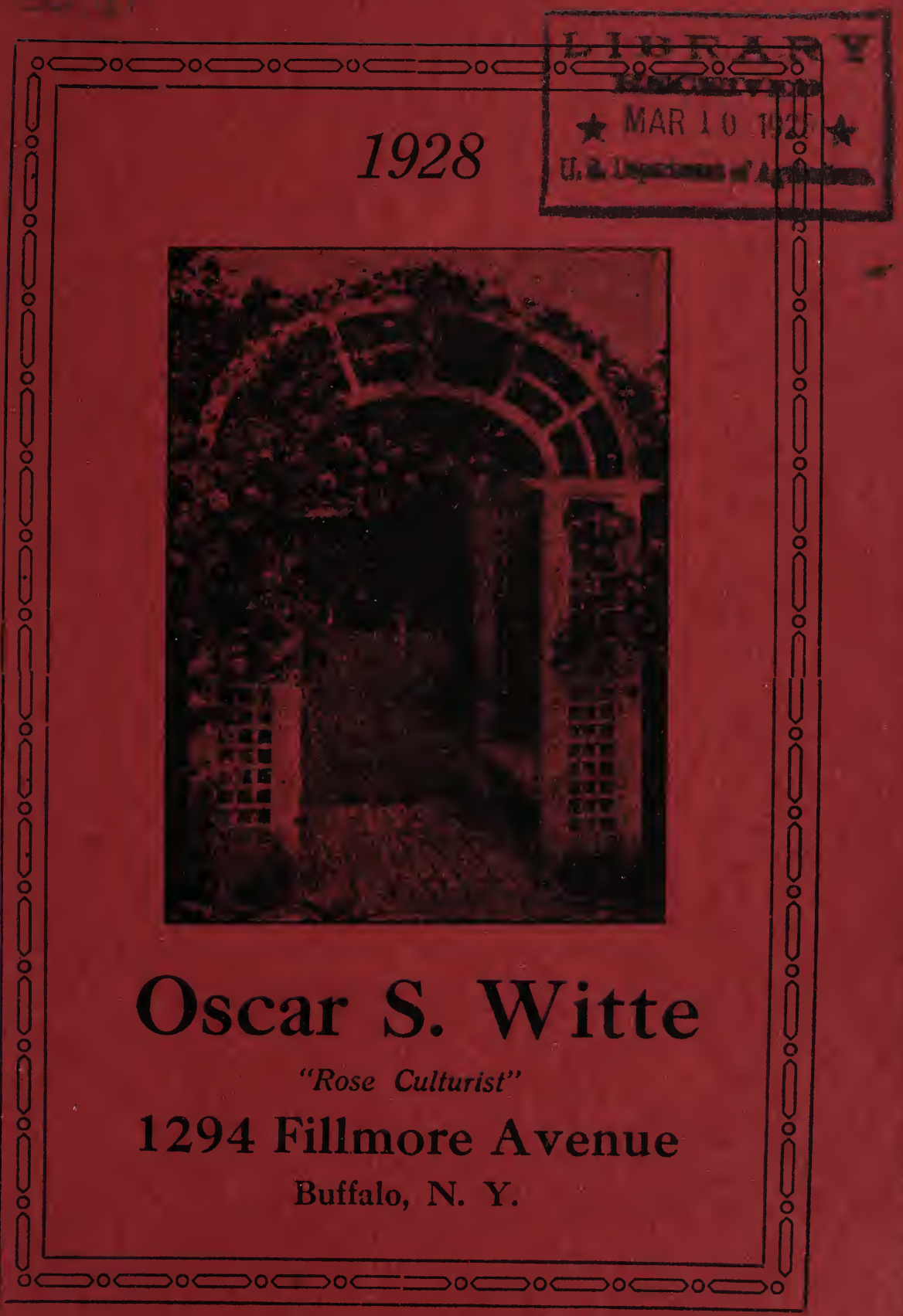




\section{"THANK YOU"}

"I wish to take this opportunity of thanking the many customers and friends who have favored me with their orders in the past and hope for a continuance of their patronage.

\section{Suggestions:}

ORDER EARLY - As soon as this catalog reaches you, send in your order. It greatly facilitates shipment if orders are received early. Orders for one or 51 will receive the same careful attention. Shipping season commences in early April.

GUARANTEE - All stock is guaranteed to be healthy, of high quality, true to name, and reach you in excellent growing condition. If found otherwise stock will be replaced without charge, or money refunded. All claims must be made. within 10 days from date of invoice.-It is my policy to communicate with each and every one of my customers during the growing season to ascertain the results obtained by purchasing plants from me. This information is not for advertising purposes but to promote goad will between the customer and myself. It is my endeavor to grow and furnish at all times the very best quality of nursery stock possible, at the most reasonable prices.

TERMS--

Cash. A discount of 2 per cert. allowed on orders of $\$ 10$ or more accompanied by cash.

ALL ROSE LOVERS are urged to join the American Rose Society, a society organized to stimulate and conduct rose hybridization and other research work upon rose improvement and in regard to insects and diseases inimical to the rose. Write to Robert Pyle. Secretary, A. R.S.. West Grove. Pa., for further particulare. 


\section{RGSE CULTURE}

sull-All varieties of roses do not thrive equally well in the wame kind of soil. Hybritl I'erpetuals and the stronger Hybrid Teas do better in w heavy elay loar: , and the weaker Hybrid Teas and Teas in a warmer and mare sandy loam. One should not be deterred from planting roses if he iroes not have these conditions or the means of producing them, for roses wive satisfactory results on a wide range of soil eonditions. Sore failures; wreur from a lack of nourislment in the soil than fom any other single ause. The ordinary garden soil will grow good roses if well enriched with ،ow manure or decomposed barn-yard manure.

PIROPER DRAINAGE is an essential in rose culture, as the plants svill not thrive in excessively wet soil. If the subsoil is impervious and the beds are on slopiu's gronne so that an outlet can be easily arranged, they should be tile-drained; ofherwise a six-inch layer of stones, gravel, broken bricks or clinkers should be placed in the bottom of the excavation and on top of this a layer of soils with grass side down. Above this should be at least cighteen iuches of mood soil.

A. Shows depth to plant.

IB. Shows where plant was budiled.

C. Show height of 8 to 10 inches of earth drawn plant for winter protection, after which the surface should bo mulched with six inches of coarse litter or manure.
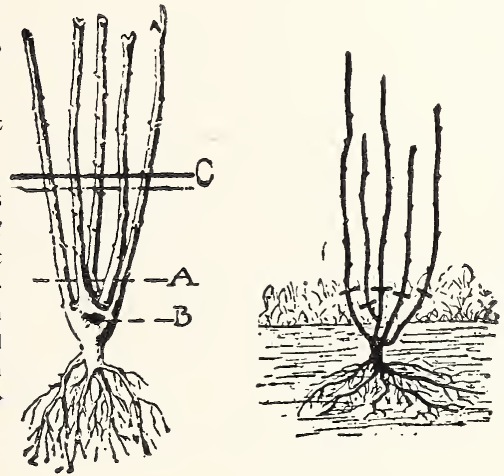

I o s properly planted with the roots spread out as thoy should be. The crossmirks on the stens show where to prune after planting.

LOCATION-The rose bed or garden should bo lceated in a sumuy. open place sheltered from sweeping west or north winds. Caution nust be used so that the beds are not placed in too elose proximity to trees, the roots of which will rob the rose beds of all moisture and plant-food.

CULTIVATION-As soon as the plants are set, the beds should be leveled, eare being taken to see whether each plant is set at the proper depth. Throughout the growing season, the soil should be frequently stirred with hoe and rake so as to maintain a muleh of finely pulverized soil over the beds. The soil should never be allowed to bake if a supply of flowers is desired. Plants secure their food from the soil through minute hairline aipendages on the roots. All food taken up by the roots is sceured in solution and this makes it necessary to kee? the soil properly supplied with moisture, thmough eultivation. Air must be present in the soil or it will be inpossible for the root hairs to secure the necessary food for the plant. The air in the soil must mostly come f:om the surface so it is obvious that it is always necessary to keep the surface in sue! a condition that it will admit air. through eultivation and deep plowing. Cultivation also goes far in kecping insects and diseases under control. Many insects' (*grg and larvac and many disease germs are found in the soil. When the spound is stirred frequently, these are brought to the surface and exposed 10) the hot sun and many of them are thus destroyed.

Cse a fertilizer when it is a solutely necessary, but make sure, first that some cheaper process, such as eultivation, drainage or rotation will not accomplish the same result. The physieal condition of 11 , sil in fractically every case is more important than the chemical condition. that is, it has a more direct effect upon the plants. 


\section{THE CULTURE OF GARDEN ROSES}

THE culture of roses is too broad a subject to treat in all its phases - in this catalog, but suggestions for growing roses successfuily in ; ardens and home grounds will be given on request. There is no secret in the growing of good roses. The proper location, rich, well drained and well cultivated soil, and safe guarding against fungus and insect pests, will an contribute to the health and vigor of the plants. The varieties described are considered to be of the leading kinds. When properly planted and cared for, they will give perfect satisfaction and will bloom six woeks after planting. The stocks are FIELD GROWN, two and three years old, of HIGH QUALITY. BUDDFD on proper stocks, best adapted to their growth. Plants are guaranteed in every respect or moncy refunded. Unless otherwise stated, prices are 90 cents per plant.

\section{Special Offer, 6 for $\$ 5.00-12$ for $\$ 9.00$}

\section{Hybrid Teas or Everblooming Varieties}

\section{(Blooming Season, June Until Late Autumn)}

AMALIE DE GREIFE. HT. (P.
Lambert, 1912.) Ovoid buds of brick-rose, and large, well-formed, globular flowers of fine substance and petalage, paling as they open to light shell or salmon-pink, deeper in center. Grows well and blooms steadily hroughout most of the season. Foliage is soft and little bothered by disease. A most attractive rose whose unusual color ought to win it a place in all good corlections.

ANGELE PERNET. HT. (PernetDucher, 1924.) Brownish orange blooms of excellent shape, although only semi-double, and the color is well retained; some fragrance. Plant is of moderate growth. $\$ 1.25$ each.

BETTY UPRICHARD. (A. Dickson \& Sons, 1922.) Copper-red buds, wpening to semi-double (17 petals? flowers of above average size. Brilliant orange-carmine on outer surface of petals, showing light salmon reflexes; spicy fragrance. Stronggrowing, persistent blooming and healthy. Price \$1.25.

BRIARCLIFT. New, bright silvery rose, slight golden base, pointed bud. Price $\$ 1.25$ each.

CHARLES K. DOCGLAS. (H. Dickson, 1919.) Fine, long pointed buds, opening to large, loosely formed flowers of striking crimsonscarlet, slightly rragrant. Strong branching growth and abundance of healthy foliage.
COLUMBIA. Glowing pink. The flowers are large. Said to be free from mildew and spot.

DAME EDITH HELEN. HT. (A. Dickson \& Sons, 1926.) Shapely buds and substantial, high-centered blooms of clear pink, sweetly scented and freely produced on long, strong sten:s. Vigorous and healthy. $\$ 3.00$ each.

EIDORADO. (Howard \& Smith, 1923.) Golden buds, flushed with red, opening to clear yellow, cupped blooms filled to the center with crinkled petals; sightly fragrant. Erect plant with fairly good foliage, blooming well in early sunimer an.i fall. Price $\$ 1.25$.

ETOULE DE NRAXCZ. Vivid crimson with darker shadings. Fragrance and sturdy growth especially recommend it as a garden rose.

ETOILE DE HOLLANDE. HT. (H. A. Verschuren \& Sons, 1919.) Brilliant red blooms of magnificent size, perfect in have-open state, showing clean, attractive centers when fully open; petals enormous; very fragrant. Plants branching, particularly free flowerling and healthy. A splendid rose with no serious faults. Color holds ramarkably well, becoming lighter instead of bluing. The buds are a little small but open beautifully. Toward fall, the flowers are larger, fuller, and darker 
red. Easily the most dependable and easy-growing red rose with anything like good form. In fact we have no hesitation in saying it is the best red rose grown today. $\$ 1.50$ each.

FEU JOSEPH IOOYMANS. HT. (P. J Looymans \& Co., 1922.) Long pointed buds, resembling those of Sunburst, and large, fairly full flower of yellow, with vivid apricot tints, giving it a brilliant effect in the center. Growth strong, straight and bushy. Recommended abroad for gardening and exhibition purposes. Here the very long, firm buds are brilliant orange-buff, strongly suffused with yellow. The flowers are well-formed, on extremely strong stems; attractive and pleasing when several days old. The foliage is hard; stiff glossy sreen. $\$ 1.50$ each.

IRAYCIS SCO'T KEY. Deep, even red, large very double. A giant in srowth, producin: long stout canes

GENERAL MoARTIIUR. A grand rrimson scarlet rose. It is a very free-blooming, every shoot producing a beautiful and richly colored bud and flower. The flowers are large, double. Very fragrant.

GOLIEN EMBELM. (S. McGredy \& Son, 1917.) Rich, deep golden yellow of good substance and mildew resistance. 95 cents each.

GRUSS an TEPLITZ. Scarlet; consantly in bloom. A good border bush.

INDEPENDENCE DAY. HT. (Bees Ltd., 1919.) Flaming yellow buds, heavily shaded with copper and brown, opening quickly to a moderately large flower of 15 to 20 petals which rapidly fades to light orangepink. Strong, upright, branching habit. Flowers are thin and only medium size, but very freely produced-the bush is almost always covered with budis and bloom. Probably the best of a "half-dozen new brilliantly colored varieties of the IIne. Edouard Herriot type. $\$ 1.25$ each.

INNOCENCE. (Chaplin Bros., 1921.) Very large, sincle, pure white flowers with prominent orange-red stamens. The plant makes strong upright growth, and bears dark, mildew - proof foliage. Flowers often 5 inches across when several days old. Most attractive single rose. Price $\$ 1.75$.
IRISH BEAUTY. (A. Dickson \& Sons, 1900.) Cream white with yellow stamens, very fragrant and free flowering. Foliage especially good, excellent growth.

IRISH ELEGANCR. (A. Dickson \& Sons, 1905.) Bronzy pink buds, opening with shades of apricot and yellow. Very strong growth and continually in flower.

ISOBEL. (S. McGredy \& Sons. 1916.) Exquisitely pointed buds and flowers with huge petals. flushed with carmine-red and orange, becoming pink with age. Fragrant. A fioriferous plant, needing plenty of room.

JOHN RUSSELL. HT. (Dobbie \& Co., ¿td., 1924.) Large ovoid buds and immense crimson flowers of the old-time globular type with the famous exhibition center. Plant exceptionally strong and vigorous. Surely it is one of the handsomest red roses, and creates a stir whereever it is seen. Everyone will want it for its splendid color and form. Price $\$ 1.25$.

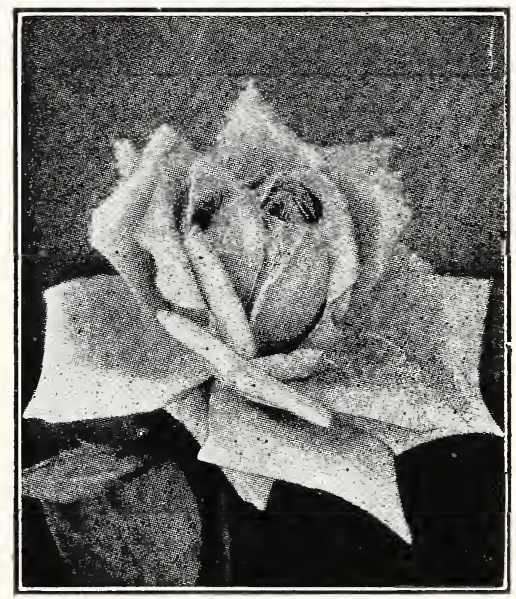

\section{Los Angeles}

KAISERINE AUGUSTA VICTORIA. A standard old sort, producing large, full, globular blooms of creamy white, shading sometimes to delicate primrose.

LADY AIICE STANLEY. Shellshaped petals of deep coral ros: outside, interior delicate flesh suffused pink. A persistent and free blonmer. 
LAD ASHTOWX. Pale rose shading to yellow at base of petals. Excellent for garden and a profuse bloomer until frost.

IADY HILLINGDON. Deep apricot yellow. Plant relatively hardy, of much vigor and with an autumnhlooming habit.

IAEUTESANT CHACRE. Velvety crimson-red, shaded with garnet; flowers large on a vigorous plant.

LOS ANGELES. The growth is very vigorous, and prouces a continuous succession of long-stemmed flowers of a luminous pink, toned with coral and shaded with translucent gold at the base of petals. The buds are long and pointed. $\$ 1.00$ each.

LCXEMBERG. A very fine yellow rose.

MME. BUTTERFLY. (E. G. Hill Co., 1918.) Sport of Ophelia, large flowers, in a brilliant pink, suffused apricott and gold. Fragrant. The plant is free and fine in growth and habit.

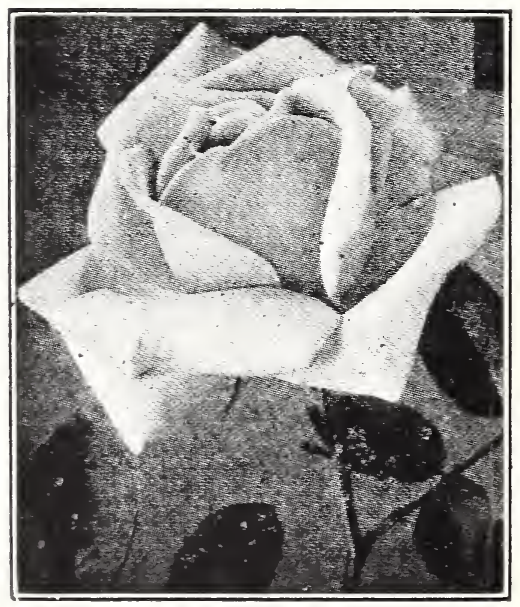

Miss Cynthia Forde

MISS CYNTHIA FORDE. Deep brilliant rose pink, shading on the back of petals to light rosy pink.

MISS I.OITA ARMOLR. The flowers are of large size, full double. with petals of great substance and? delightfully pragrant. As the flowers expand they become a deep coralred suffusion. the base of tha petals a rich golden vellow with (a)pery red sheen. \$1.00 each.
MIE. ABELI CHATENAY. (Pernet-Ducher, 1900.) Light pink blooms, shaded salmon white and carmine, of charming form. One of the most populal of all roses. The flowers are beautiful but rather small.

MAE. EDOCARD HERRIOT. (Dxily Mail). Coral-red, shaded with yellow and bright rosy scarlet, passing to shrimp-red. Famous because it won a $\$ 10,000$ prize in England, offered by the Daily Mail Newspaper.

MRS. A. R. WADDELI. Scarlet buds, opening to deep reddish saffron flowers.

MRS. A. WARD. Yellow, sometimes shaded with salmon and rose. The plant is a good grower and blooms continually. Well recommended.

MIRS. F. R. PIERSON. A sport of Premier. Bud very large. flower very large. Beautiful sardinal red. Gold Medal winner. \$1.25.

MRS. S. K. RINDGE-(Howard \& Smith, 1919.) Yellow, suffused with soft pink.

MRS. IV. C. EGAY. (Howard \& Smith. 1922.) Deep flesh-color, softly contrasted with a lighter shade of soft pink and a golden glow at the base of the petals, slightly fragrant, very vigorous branching plant with an excellent blooming habit. $\$ 1.25$ each.

MRS. WEMYSS QUIN. Canary-yellow, shaded with crimson-orange.

OLI GOLD, (S. McGredy \& Son. 1913.) Orange buds and buff flower's tinted pink, not quite single, mildy fragrant. Plant of moderate growith. Best in bud form.

OPHELIA. Its blooms are large in size, full and perfect in form and appearance and of attractive light salmon-flesh coloring shaded to yellow. Well recommended.

PHARISAER. Rosy-white, shadei with salmon. Large and iull.

PREMIER. Clear, pure shade of rose-pink. Very fragrant.

IADIANCE. Carmine-pink, yellow at base of petals. The plant is upright and vigorous, and disease resistant.

RED RADIANCE. Dazzling crimcon scarlet. Good fall bloomer. A notable and superb rose of American origin. 
REV. F. PAGE-ROBERTS. (B. R. Cant \& Sons, 1921.) Two-toned yellow and apricot, opening deeper ycllow; blooms full and large, with a decided fruity scent. $\$ 2.00$.

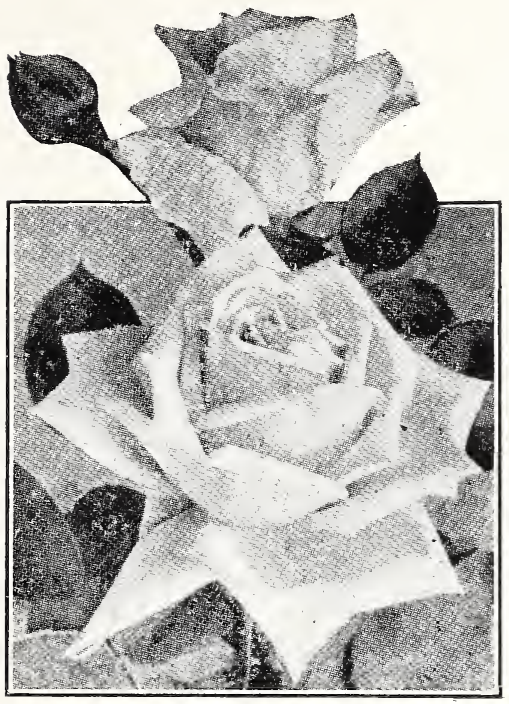

Pharisaer

ROSELA NDIA. (W. Stevens, Ltd., 1924) Sport of Golden Ophelia. Flower larger than parent and deeper in color with high-pointed center. Blooms perfect. Fragrant. Price $\$ 1.25$.

SILVIR COLUMBIA. Sport of Colurnbia. Same as Columbia only silvery shade. Price $\$ 1.25$.

SOUVERNIR de CIAUDIUS PERNET. (Pernet-Ducher, 1920). By all means the best yellow rose ever produced in Europe. It was awarded the Bagatelle prize. Its color is a definite and lovely sunfloweryellow, deeping in the center. The plants are of branching habit, with brilliant green foliage and few thorns produced on long stems. $\$ 1.00$ each.

SOUV. de GRORGES PERNET. (Pernet-Ducher, 1921.) Very large blooms of Orient-red with cochineal-carmine and yellowish shading, vigorous. $\$ 1.25$ each.

THE QUEEN ALEXANDRA ROSE. (S. MeGredy \& Son, 1918.) Globular, fairly full blooms of medium size, and unusual color-scarlert on inside and yellow on outside of petals, somewhat fragrant. $\$ 1.25$ each.

WHLELM KORDES. H'T (W. Kordes Sohne, 1922.) I ong, pointed buds and double, high-centered flowers of deep golden salmon. overspread with a tint of copper, and veined with red. Very fragrant and unusually free flowering. Vigorous, compact growth. One of the most marvelously colored roses of recent years-almost any color description would suit it at one tims or another, but it is always bright and distinct. The flower also has substance and real beauty of form, a quality rare in roses of this general type. The blooms are a trifle smaller than usual in hot weather but the color holds well. The early flowers and those produced in autumn are magnificent. The foliage is strong, leather-like and very resistant to mildew and blackspot. Price $\$ 2.25$ each.

WILLOWMERE. Shrimp, pink, shaded yellow and carmine. Always attractive.

\section{HYBRID PERPETUAL ROSES \\ 90 Cents Each, $\$ 9.00$ Per Dozen, \$70.00 Per Hundred 50 at the Hundred IRate \\ (June Roses)}

ALFRED COLOMB. (Lacharme, 1865.) Strawberry-red, with crimson-carmine reflexes. Full, very free, hardy.

BARON de BONSTETTEN. (Liabaud, 1871.) Deep velvety crimson. Deliciously fragrant.

BARONISS ROTHSCHILD. (Pernet, 1S67.) Dainty pale pink is the color of this superb Rose, large in size and symmetrical in form. Fragrant.

BLACK PIRNCE. Very dark erimson. Fragrant.

CAPTAIN CHRISTY. (Lacharme, 1873.) Plump and heavy buds with backward-curling petals, including both light and dark pink colors. Rather dwarf grower. 


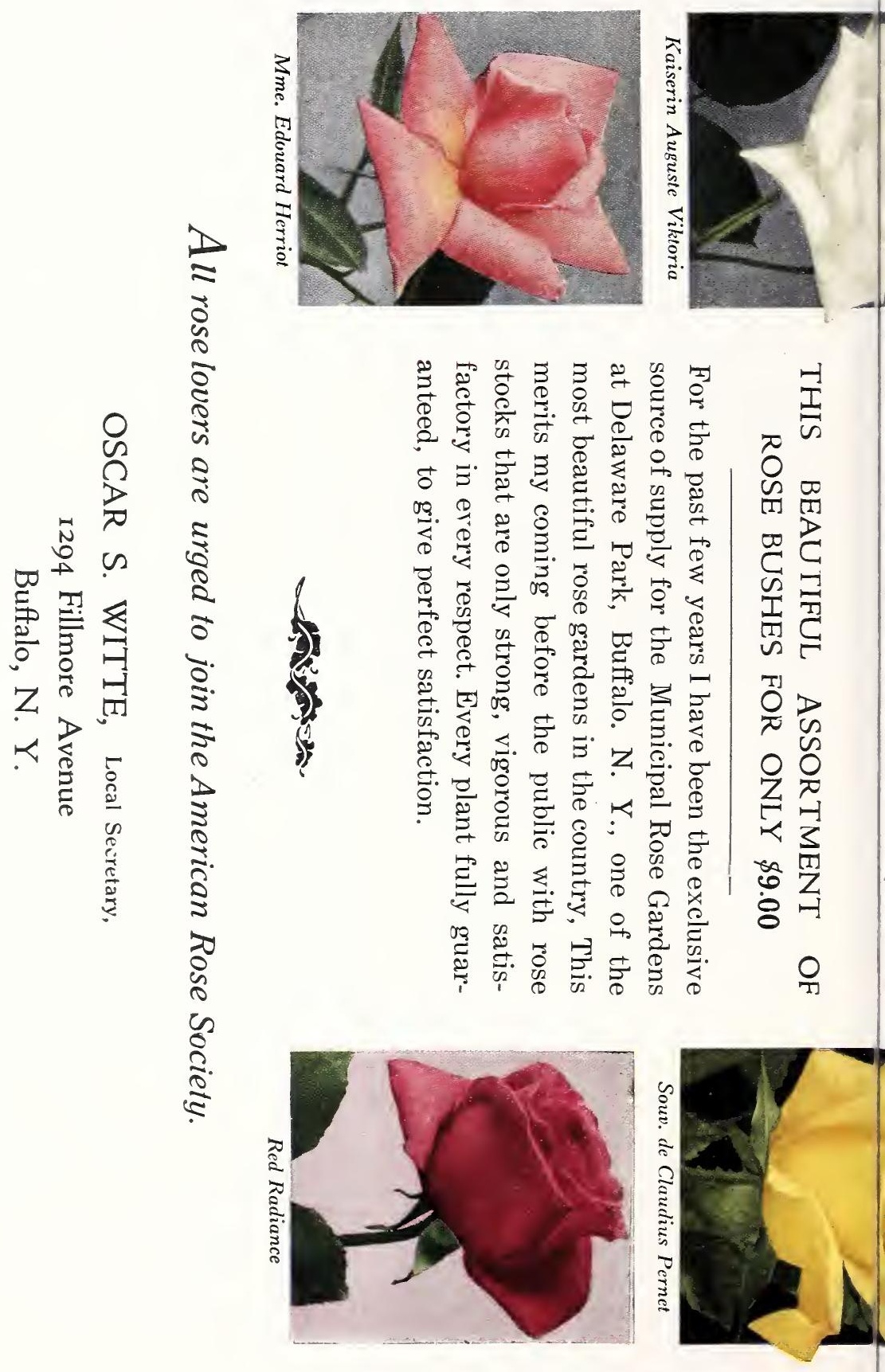


COQUETTE des BLANCHES. Creamy white. Good bloomer.

EUGENE FURST. (Soupert and Notting, 1876.) Brilliant crimson flowers with dark purple shadings, sweet-scented. Vigorous grower.

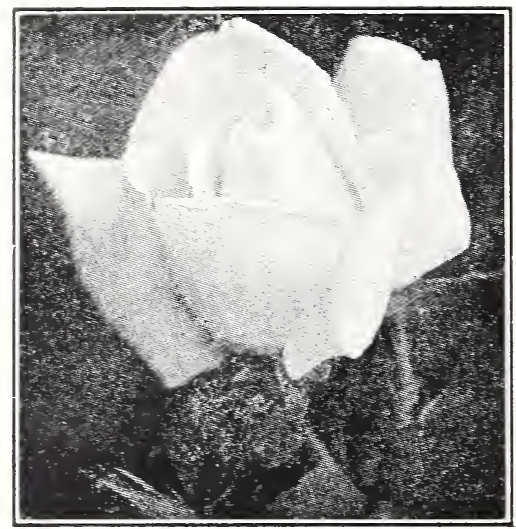

Frau Karl Druschki

FRAU KARL DRESCHII. (Lambert, 1900.) Most popular Rose in America. Its pure snow-white, unshaded blooms are of immense size. plant grows rery strongly.

GENERAL JACQTEMINOT. Bright crimson, very free flowering. Flowers are large and sweet.

GEORGE ARENDS. (Hinner, 1910.) Known as "Pinis Druschli." Tell shaped, delicate pink buds of pure, eren color. opening into large and beautiful flowers.
GLOIRE de CHED.NE-GLINOISSEAC. Large, full, globular flowers of vermilion-red.

GLOIRE LYONNAISE. White, tintsd yellow, deeper in center, with go d fragrance in a large flower.

HEINRICH MUNCH. (Munch \& Haufe, 1911.) Literally immense blooms of soft pink, splendidly formed, borne on vigorous plants inclined to bloom in the autumn. Often sold as Pink Frau Druschki.

HCGH DICKSON. Intense crimson, shaded scarlet, are the large and full flowers of this sweetly rose.

J. B. CLARKE. Deep scarlet, shaded blackish maroon. Strong rariety.

LUDIVIG MOLLER. ( $\mathrm{H}$. Kiese \& Co., 1914.) Knomn as the "Yellow Frau Karl Druschki." Deep yellow blooms of good form, changing to pure white.

MARGARET DICKSON. White, with pale flesh center. Gold Medal Rose. Plant is very vigorous.

MRS. JOHX LAING. (Bennett 1887.) Large blooms of soft, clear pink. Plant is a strong grower.

PACL NEIRON. (Levet, 1869). The largest rose in commerce individual flowers reaching 6 inches in diameter. Flowers are clear pinis, shading to rose culor.

RUHM VON STEINFCRTH. "Ped Frau Karl Druschki" New Rose $\$ 1.25 \mathrm{each}$.

CIRICH BRCNNER. Large flowers of light red. cup-shaped flowers. Free bloomer.

\section{HARDY RAMBLERS AND CLIMBERS so Cents Each-\$S.00 Per Dozen}

ALIDA LOVETT. (Dr. Tan Fleet, 1905.) Bright shell-pinl flowers of Hybrid Tea size and quality, lightly shaded with sulphur-yellow at base of the petals, faintly perfumed. Plant extriz strong, with heary, thorny cunes and perfect foliage,

AMERICAN PILLAR. Large single flowers, cherry pink with clear white eye. Canes of vigorous srowth.

AVIATELR BLERIOT. H y b r d Wichuraiana, Fauque et Fils, 1910. Clusters, saffron yellow, center golden rellow. Foliage last quite well.

I3FSS LOVETT. H. W. (Van Fleet. 1905.) Produces many large and fragrant flowers of clear, bright crimson. double, full cupped anc oi notable lasting quality. One of the best roses grown by the liamented Dr. Van Fleet, whose hardy climbers are of world-wide reputation.

BLOOMFIELD COLRAGE. (Capt. Thomas, 1925.) Small, dark velvety red flowers, with white center's and prominent vellow stamens, produced in good sized clusters along 
the entire branch. Very free flowcr.ng habit and very hardy. Vigorous grower, dark green, healthy foliage. $\$ 1.75$ each.

CHRPTHNE WRIGHT. Cross between Caroline Testout and a Wichuraiana seedling. Placed with $\mathrm{Hy}-$ brid Tea climbers on account of the fact that its flowers are large and double, borne singly and in clusters, good form. with a perfect bidd and good petallage, color is wi.d rose pink, requires no protection. Blooms vest in spring. A few scattering flowers in autumn. A very satisfactor 3 climbing rose. Foliage lasts os 8 !!

\section{CLIMBING AMERICAN BEAUTY.}

Red flowers like bush rose of that name. Of a very strong habit of growth, producing shoots ten to fifteen feet long in a single season.

DR. HUEY. (Thomas) 1904. Totaliy different from any other rose in existence. Semi-double flowers of dark crimson-maroon of deepest scarlet. The flowers are large and borne in clusters. Never fades "blue."

DOROTHY PERIINS. Great clusters of pretty double-pink for a long season of the year.

COCTOR VAN FLEET. This variety shows a mass of beautiful clustered buds, which open out into large, shapely flowers; delicate flesh white. An admirable cutting variety.

EMII,Y GRAY. (H. W. Williams, 1918.) A very remarkable new climbing rose, semi-double flowers in golden yellow. Deep glossy fo: iage. Awarded Gold Medal in Englar 1 Price $\$ 1.00$ each.

EVANGELINE. ( $M$ H H. Walsh, 1906.) Rather large, single flowers with dieinty reflexed petals of rosy white, tipped with pink, very fragrani. Clusters very large and abundantly produced by ic strong plant, 12 to 15 feet high.

EXCELSA. (M. H. Walsh, 1910.) Double, scarlet-arimson blooms with light streaks and shaded. Clusiter's very large and produced with utmost profusion. Plant is extraorc.inarily vigorous but not immune to mildew.

FELICITE ET PERIETUE. Sempervirens (Jacques, 18:7). Fairly large, very double roses, flesh- white in bud but pale cream when open. Cluster Clowering. Very vigorous, liarly with bexutiful, almost evergreen foliage. Graceful and ornamintal when out of flower.

WRAULEIN O C T A I A HESSE: (Hesse, 1910.) Creamy white flowers with yellowish center, fairly large, very well formed, fragrant borne singly or in sparse cluster: on long stems. Plani very stronis, foliage good, and notably liberal in bloom.

FIRAU LINA STRASSHEIY. (Stra.ssheim, 1907.) Flower's of reddish salmon-pink, in strong well-filled clusters which last well. Upright growth with stiff, vigorous growth.

GARDENIA. (W. A. Manda, 1889.) Yellow buds and cresmy-flower. with rich yellow centers, moderately large, well formed, and borne in small sprays. Plant extremely vigorous, hardy in all but the severest climates. Prices 75 cenits.

GLOIRE de DIJON. Noted for the great size of its flower, its delicate tea scent and its shade of color, being a creamy buff on the outer petals, tinting orange-yellow toward the center. A strong grower.

GOLDINCH. Hybrid Polyantha. Pale orange, changing 'to white, semi-double, trusses. Reported stronger in North than the Hybrid Wichuraianas.

GRUSS an FREUNDORF. (F. Pra:kac, 1913.) Dark, velvety crimson flowers in immense clusters, rather. large, semi-double, with whitish center and bright yellow stamens. Splendid, vigorous growth.

IIIART OF GOLD. A Van Fleet hybrid. This rose puts into rose circulation new blood through the rare red Chinese Rosa Moyesi as pollen parent. It is christene.l "Heart of Gold" by reason of its abundant stamens, showing in the center of a large and bcautiful "blackish crimson." Single flowers in which a band of clear white separate the crimson and the gold. 'the plant is vigorous and slightly as a bush or a pillar rose Drice $\$ 1.25$.

IIA WATHA. Single. Deep intense crimson, shading to snowy white at the base.

IADY GAY, H.W. (MI. H. Walsh, 1913.) We consider this variety the same as Dorothy Perkins . T5: each. 
MARY LOVETT. H. W. (Van Fleet, 1915. Broad, large and handsome open flowers, much resembling a Hybrid Perpetual Rose and a pure waxy white; one of the best of the white climbers.

MARY WALLACE. The attractive new climber raised by the late Dr. Van Fleet and first disseminated last year by the American Rose Society. Semi-double, bright clear rose-pink, with salmon base to petals.

MAX GRAF. Cl. Rug. (Bowditch, 1919.) Large single flowers of shining pink, freely produced at its season. Plant is prostrate, and trailing with glossy, wrinkled foliage.

MILIT IVAY. ( MI, H. Walsh, 1900.) Pure, waxy white, o: je flowers, clustered in overwhelming abundance upon a very vigorous and extremely hardy plant.

PACL'S SCARLET CLIMBER. Vivid scarlet, The flowers of this new rose are semi-double and produced in clusters. The plant being literally covered with flowers from top to bottom. It is strong climbing habit and hardy. Won three gold medals in England and France. $\$ 1.00$ each.

PHILADELPHIA RAMBLER. The flowers are double, glowing crimson, of good substance and mildly fragrant. Borne on large clusters. Very attractive.

SILVER MOON. Silver white with yellow stamens. of remarkably strong growth. Very distinet. Extra large.

STAR OF PERSIA. The golden yellow, semi-double flowers are about three inches across and with petals of remarkable substance and firnmess. The plant is reported to be hardy and vigorous as a low climber. Price $\$ 1.75$ each.

TAUSENDSCHON. Hybrid Polyantha. Soft pink, large clusters, foliage last fairly well. Reported hardier in the North than the $\mathrm{Hy}$ brid Wichuraianas.

WEDDING BELLS. H. M. (M. $H$. Walsh, 1907.) Deep rose pink, semidouble flowers, borne in large drooping clusters on a very energetic plant, with strong, downy foliage growing 12 to 15 feet in a season.

WHITE DOROTHY PERKINS. Similar to Dorothy Perkins, but white.

\section{POLYANTHA ROSES \\ ־e Cents Each-\$70.00 Per Hundred}

Polyanthas are the most truly everblooming of all roses, scarcely ever out of flower during the whole growing season. Ther are dwarf, bushy plants. and bear small flowers in enormous. many-flowered elusters. They are rapidly gaining in favo" and popularity with all who appreciate beauty in minature as well as in its mere imposing aspeets.

ANYCHEN MULLER. (J. C. Schmidt, 1907). Large ciusters of mediunsdouble deep rose flowers from June until late autumn.

I ECILE BRUNNER. (Mme. Ducher. 1881). Bright rose flowers, wich yellowish center, borne in clusters, and fragrant.

EILEN POCLSEN. (D. I. Poulsen, 1912.) Rather large, fairly full flowers of bright rose pink, darkel towards the edges and slightly fragrant. Large compact clusters, borne profusely by a dware bushy plant 15 to 18 inches high.

FVEIN THORNTON. (Bees Ltd., 1919.) Pinkish vellow buds and pale pink and sold flowers, rather large, almost single, borne in immense loose sprays, Lovely apple. blossom flowers.
FRAC DR. ERRETH. (Geduidi二, 1915.) Flowers very large for a Polyantha, deep golden yellow, becoming white with age, very double, well shaped, and borne in sparse c lusters. Noderate, branchin: growth, healthy and hardy.

GRETA KLCIS. (Kluis \& Koninz, 1915.) Medium-sized, double flowers of deep pink, passing to carmine-red, slizitly fragrant, produced abundanily throughout the season in small bunches on dwart bushy plants with normal foliage, hardy and dependable.

GRUSS AN AACHEN. (P. Geduldig, 1909). Very large flowers of fiesn pink overlaid with creamy yellow and shading to deep pink at the base of broad petals. Plant vigorous and free bloomer. 
MAMAK TIRBAT. (E. Turbat \& Co., 1911.) Small, rounded flower of China-rose, shading to lilec, semi-double, long lasting, in large clusters. Plant 12 to 15 inches high, good foliage, very hardy.

MISS EDTTH CAVELL. Brilliant scarlet held right through until the flowers drop off. Plant is vigorous and satisfactory.

ORLEANS. (Levavasseur \& Sons, 1910.) Flowers small, fairly double, and brilliant light red with a whitish center. Blooms without cessation in big compact corymbs. Plant is very strong and healthy.

PERLE D'OR. Flowers of yellow. toned orange in the center.

RODHATTE. Bright cherry-red flowers, semi-double.

TIP-TOP. (Lambert, 1909.) A very different variety, producing many buds of refined Hybrid Tea form, tipped with pale or deep rose, the inner petals golden yellow, striped and splashed with pink.

TRIOMPHE ORLEANAIS. (Peauger, 1912.) Bright cherry-red, wellfilled flowers, large for the class, produced freely in large trusses. Long lasting and fades very little. Plant strong and erect. 20 to 30 inches high, with glossy, bright green foliage.

YVONNE RABIER. Pure white with yellowish shading at the lbase of the petals. Probably the best of the white Polyanthas.

\section{Rugosa Roses and Their Hybrids}

\section{5c Cents Wach, 12 for $\$ 8.50$ $\$ 70.00$ Per Hundred}

All of the Rugosa Roses bloom abundantly in the spring. The plants reach 5 to 8 feet in heigh:h, and are very hardy. May be planted as specimens in lawns.

ARNOLD. Single blooms of rich, slowing scarlet.

CONRAD F. MEYER. The flowers are very large, double, and fragrant. Color, silvery rose.

F. J. GROOTENDORST. Flowers are in clusters and of a red carnation color. Blooms from June until frost. $\$ 1.00$ each.

HILDENBRANDSECK. (P. Lambert, 1909.) S emi-double, shining-carmine flowers of medium size, borne in clusters on the tip of every shoot during the season. Very vigorous and very hardy.

ROSERAIE DEIHAY. (CochetCochet, 1201.) Dark red, doublo flowers with a strong, most pleaing perfume. Blooms very early is spring and continues throughout th summer. Vigorous and hardy.

ROSA HUGONIS. (Native of Weatern China.) This Chinese Rose gives us the only dependable yellow rose. The plants grow rapidly, and may reach a height of 6 feet when matured. The long arching branches are closely set with lovely single flowers very early in the season. The bilooms are approximately $1 \frac{1 / 2}{2}$ inches across, and of clear bright yellow which does not fade. Very hardy. Foliage of light green is very attractive and makes an unusual lawn specimen. Disease resistant. Price $\$ 1.50$ each.

RUGOSA ALBA. This is a white form of the native Japanese species. Its blooms often measure 3 inches across, and are produced singly or in clusters. Blooms are followed by brilliant red frusts or heps.

RUGOSA. (Thuniorg, 1784.) Large single flowers of soft crepe-like texture, fragrant, and rather fleeting. Color varies through shades of pink. magenta, and rosy crimson. Blooms very early, continuing until autumn. Disease resistant.

SCHNEELICHT. (Geschwindt, 1896.) Dazzling white, fairly large flowers, produced in clusters on a strong. climbing plant with all the other desirable Rugosa characteristics. Very hardy and free flowering.

\section{MOSS ROSES}

\section{Cents Each, 10 for $\$ 6.50$}

Moss Roses. The flower is surrounded by a mossy excrescenze which gives it distinction and beauty. Blooms are exceedingly fragrant, when produced in June.

BARON de WASSENER. Light crimson.

BIANCHE MORFAU. Flowers ale large and full, pure snowy white and produced in clusters.

CHAPEAU de NAPOLEAN. A tragrant sort of pale rosy pink.

RED MOSS. Large flowers of clear red and heavily mossed with desp green. 
SALET. (Lacharme, 1954.) Deep, rosy pink; very large and double with a true moss odor.

\section{Lambertiana Roses}

55c Cents Each-\$50.09 Per Hundred

A class of roses new to this country. Originated by Peter Lambert of Germany. They tend to be climbing roses which bloom more or less frequently during the season.

ARNDT. (P. Lambert, 19:3.) Reddish yellow buds and salmon-rose flowers of medium size in large loose clusters. Flowers until fall.

FXCELLENZ VON SCHEBERT. ( $P$. Lambert, 1909. small double flowers of dark carmine-rose, borne in dense clusters of 5 to 20 c,n the tips of every shoot. Vigorous, 4 to is teet high. Hardy.

GFHEIIRAT DR. MTTWEG. (P. Lambert, 1909.) Rosy pink flowers wits pale yellow centers, borne in large truszas. Growth strong.

KOMMERZIENR:'Y IV. RAUTENSTRACCH. (P. Lambert, 1909.) Pure salmon-pink flowers with yellow centers and lighter backs. Growth strong to 8 feet or more.

KORNER. (P. Lambert, 1914.) Large clusters of reddish buds and double, well-shaped flowers of orange-yellow w:th salmon tints. Plant vigorous, up to 10 feet.

Hybrid Sweetbriers, Austrian Brier, Damask, Galliaa, Miscellaneous Roses 75 Cents Each-\$70 Per Hundred

AMY ROBSART. Bright rose flowers. Vigorous.

\section{AUSTRIAN COPPER. (Gerarde,} 1596.) Single flowers of intense copper-red, reverse of petalis bright golden yellow. Hardy.

\section{GLOIRE DES ROSOMANES, 11.} CHINA. (Vibert .1825.) Brilliant red flowers with shaggy centers, fragrant and free flowering. Strong, shrubby growth and continuous bloom. Widcly known as Ragged Fobin. Excellent for hedges.

\section{IARRISON YELLOW. (Harrison,} 1830.) Semi-double, bright yellow flowers covering the big bushes early in the season. Very vigorous and hardy. The best yellow for cold climates.

HERMOSA. ( Warcheseiu, 1840.) Medium-sized, symetrically double flowers of soft pink, borne in sprays on stout healthy plants, always in bloom.

IADY PENZANCE. Eright coppercolored flowers of most brilliant shcen. Growth 5 feet in height.

ROSE BRADUARDINE. Clear rosepink flowers, borne in rlusters.
ROSA CAROLINA. Linnaeus, (Eastern United States). Bright ros? pink flowers borne singly and in clusters on a vigorous shrub. 3 to 6 feet.

FOSA D.MASCENA. ( M i l l l e r.) Double, rose-pink blooms in small corymbs intensely fragrant. Green, very thornly canes. The famous Damask Rose brought from the Orient by the Crusaders and one of the ancestors of the Hybrid Perperual and Hybrid Tea Roses.

ROSA GALLICA. Linnaeus (Europe and Western Asia). Single, deep pink to crimson flowers, 2 to 3 inches across. Dwarf, erect bush. One of the ancestors of the Hybr:d Perpetuals.

ROSA LAEVIGAT. Michaux (China and Formesa). Cherokee Rose. Fragrant, pure white flowers, 2 1-2 to 3 1-2 inches across, borne singly in early summer. Strong, climbing growth. Not hardy in the North.

FOSA ODORMTI, Sweet. (Western China.) Large, pale nink flowers, very fragrant, strong growth. The parent of the Tea and Hybrid Tea rioses. Fairly hardy in the North. 



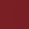

